\title{
Results from experiments comparing aqueous and anhydrous ammonia with 'nitro-chalk' for grass cut for silage
}

\author{
By F. V. WIDDOWSON, A. PENNY AND R. C. FLINT \\ Rothamsted Experimental Station, Harpenden, Herts.
}

(Received 12 April 1973)

SUMMARY

In five experiments made at Rothamsted from 1966 to 1970 'Nitro-Chalk' (ammonium nitrate-calcium carbonate mixture, $21 \% \mathrm{~N}$ ) was broadcast for grass cut for silage, either in a single dose in spring or divided equally for three cuts. The 'NitroChalk' was used to evaluate anhydrous ammonia $(82 \% \mathrm{~N})$ in 1966 , anhydrous ammonia and aqueous ammonia (approximately $26 \% \mathrm{~N}$ ) in 1967, 1968 and 1969, and anhydrous ammonia, aqueous ammonia and aqueous urea $(18 \% \mathrm{~N})$ in 1970 . All these fertilizers were applied to give $125,250,375$ and $500 \mathrm{~kg} \mathrm{~N} / \mathrm{ha}$, except in 1968 when $250,375,500$ and $625 \mathrm{~kg} \mathrm{~N} / \mathrm{ha}$ were given.

Anhydrous ammonia gave smaller yields (of dry matter) than the other $\mathrm{N}$ fertilizers except in 1968, a wet year, when it was at least as good as 'Nitro-Chalk', but slightly less good than aqueous ammonia. Yields were larger with autumn- than with springinjected aqueous ammonia and larger with either, than with equivalent single doses of 'Nitro-Chalk'. Yields with aqueous ammonia were also larger than with 'Nitro-Chalk' divided equally for three cuts when more than $375 \mathrm{~kg} \mathrm{~N} / \mathrm{ha}$ was tested, but smaller with less. Aqueous urea was as good as a single dose of 'Nitro-Chalk' but less good than divided 'Nitro-Chalk' in 1970, the only year it was tested. 'Nitro-Chalk' divided equally for three cuts gave larger yields than when a single dose of up to $375 \mathrm{~kg} \mathrm{~N} / \mathrm{ha}$ was given, but with more $N$ than this a single dose was better.

Apparent recovery of $\mathrm{N}$ was least from anhydrous ammonia and differed little between autumn and spring injection in 1968, the only year when a valid comparison was possible. Apparent recoveries of $\mathrm{N}$ from autumn and from spring-injected aqueous ammonia and from 'Nitro-Chalk' broadcast in a single dose differed little, nor did the proportion of the $\mathrm{N}$ recovered at each cut. Recovery from 'Nitro-Chalk' broadcast in three equal amounts was more uniform, but little larger.

Judged by yield, no more than $375 \mathrm{~kg} \mathrm{~N} / \mathrm{ha}$ was justified; grass given this amount of $\mathrm{N}$ either as aqueous ammonia or as 'Nitro-Chalk' removed approximately $29 \mathrm{~kg}$ of $\mathrm{N}$, $3 \mathrm{~kg}$ of $\mathrm{P}\left(7 \mathrm{~kg} \mathrm{P}_{2} \mathrm{O}_{5}\right), 26 \mathrm{~kg}$ of $\mathrm{K}\left(31 \mathrm{~kg} \mathrm{~K} \mathrm{~K}_{2} \mathrm{O}\right)$ and $2 \mathrm{~kg}$ of $\mathrm{Mg}(3 \mathrm{~kg} \mathrm{MgO})$ per tonne of dry matter produced.

\section{INTRODUCTION}

Because grass has a longer growing season and needs more $\mathrm{N}$ to yield well than arable crops, it is likely to be the best crop on which to use a highly concentrated slowly acting $\mathrm{N}$ fertilizer such as anhydrous ammonia $(82 \% \mathrm{~N})$. Ammonia needs no further processing before use, and, because it is the first product of $\mathrm{N}$ fixation, is the cheapest available source per unit of $\mathrm{N}$. However, special equipment is needed to inject and to seal it both in arable soils and under grass. Earliest experiments with anhydrous ammonia in the U.K. were by Hunter \& Jarvis (1953), who thought it unsuitable for grass- land because of the power needed to pull the injection knives, and by Jameson (1959) who found that the smaller yields of grass with it than with solid $\mathbf{N}$ fertilizer could only partly be accounted for by sward damage during injection. Anhydrous ammonia was first introduced commercially in this country in 1965. In 1966 we began experiments to compare it with 'Nitro-Chalk' (mixture of calcium carbonate and ammonium nitrate, $21 \% \mathrm{~N}$ ) for spring wheat (Widdowson \& Penny, 1970 ) and for grass cut for silage.

Aqueous ammonia (anhydrous ammonia dissolved in water, approximately $26 \% \mathrm{~N}$ ) was first sold to farmers in this country in 1963. It is easier 
to inject and to seal under grass than anhydrous ammonia, because it is a liquid under low pressure, instead of a gas liquefied under pressure, but Jameson (1959) found yields were little larger than from anhydrous ammonia when injected with the same machine. In 1966 we found it difficult both to measure accurately and to seal the anhydrous ammonia under the grass without loss. So in 1967 we included aqueous ammonia in the experiment and hired an applicator that had been specially adapted for trials work; this had no such problems. We used this applicator again in 1968, 1969 and 1970. (During 1969-71 we compared aqueous ammonia with 'Nitro-Chalk' for grazed grass and have published the results (Widdowson, Penny \& Flint, 1972a).)

Because we had found that yields of barley grain were as large with injected aqueous urea (urea dissolved in water to give a solution containing $18 \% N$ ) as with injected aqueous ammonia, and larger with either than with broadcast 'NitroChalk' (Widdowson, Penny \& Flint, 1972b) we included aqueous urea in our 1970 experiment.

\section{THE EXPERIMENTS}

\section{Treatments}

Each experiment was at Rothamsted on a clay loam overlying 'Clay-with-Flints' using a 3-year ley in 1966, a long-term ley in 1969, but permanent grass otherwise. All except the 3-year ley had previously been given at least $175 \mathrm{~kg} \mathrm{~N} / \mathrm{ha}$ annually for ensilage and grazing by cattle; they contained little clover. (Four fields were used; their names are below.)

\section{West Barnfield I experiment, 1966}

Anhydrous ammonia was injected in March into 3-year-old timothy-meadow fescue-white clover ley to supply $125,250,375$ and $500 \mathrm{~kg} \mathrm{~N} / \mathrm{ha}$ and compared with equivalent amounts of 'NitroChalk' broadcast either all in March or one-third for each of three cuts. These 12 treatments, together with four plots not given $\mathbf{N}$, were arranged in a randomized block design. Two of the plots not given $\mathrm{N}$ were 'cultivated' with the injector tines set at the same depth as on the plots given ammonia. There were four replicates.

\section{Bones Close experiment, 1967}

Anhydrous ammonia and aqueous ammonia were compared when injected into permanent grass to supply $125,250,375$ and $500 \mathrm{~kg} \mathrm{~N} / \mathrm{ha}$ either in November 1966 or in March. Yields from each were compared with those from equivalent amounts of 'Nitro-Chalk' broadcast either all in March or one-third in March, one-third after the first, and one-third after the second cut. These 24 treatments, together with two plots not given $\mathrm{N}$, were arranged in a randomized block design. There were three replicates.

\section{Parklands experiment, 1968}

Permanent grass was used again. The design was the same as in 1967 , but, to test the need for even larger amounts of $N$, we gave $250,375,500$ and $625 \mathrm{~kg} \mathrm{~N} / \mathrm{ha}$ instead of $125,250,375$ and 500 $\mathrm{kg} \mathrm{N} / \mathrm{ha}$.

\section{Appletree experiment, 1969}

A long-term grass ley was used. The treatments and the amounts of $\mathrm{N}$ tested were the same as in 1967.

\section{Bones Close experiment, 1970}

Anhydrous ammonia, aqueous ammonia and aqueous urea were each injected into permanent grass in spring to supply $125,250,375$ and $500 \mathrm{~kg}$ $\mathrm{N} / \mathrm{ha}$ and compared with equivalent amounts of 'Nitro-Chalk' broadcast either all in spring or one-third for each of three cuts. These 20 treatments, plus two plots not given $\mathrm{N}$, were arranged in a randomized block design. There were four replicates.

A basal dressing of $1000 \mathrm{~kg} / \mathrm{ha}$ of a fertilizer with $14 \% \mathrm{P}_{2} \mathrm{O}_{5}$ and $28 \% \mathrm{~K}_{2} \mathrm{O}$ was broadcast for each experiment.

\section{Method}

A rigid tool-bar fitted with disks and spring. loaded injection tines spaced $30 \mathrm{~cm}$ apart, each followed by a press wheel, was used to inject the anhydrous ammonia. The machine was calibrated on 'dummy' plots adjacent to each experiment. In 1966 and 1967 output was varied by regulating a valve and checked by weighing the ammonia tank before and again after injection. In 1966 the tank had to be removed for weighing, but in 1967 was weighed on a spring balance, suspended above it. When the appropriate setting had been determined for one amount, ammonia was then injected on appropriate plots and the tank reweighed. This procedure was repeated for the other amounts. In 1968, 1969 and 1970 the anhydrous ammonia injector was fitted with a land-wheel. driven variable displacement pump and a rotameter so that the amount of liquid injected on each individual plot could be read off directly. The pump setting was determined for one amount by calibration and the appropriate plots injected; the pump then was reset and the procedure repeated for the remaining amounts. Appendix Table 1 shows that this new rig was much more accurate.

The required outputs from the aqueous ammonia and aqueous urea injectors (with injection knives $30 \mathrm{~cm}$ apart) were also determined by calibration 
Table 1. Dates of applying $N$ fertilizers and of cutting grass in each experiment

\begin{tabular}{|c|c|c|c|c|c|c|c|c|c|}
\hline \multirow[b]{2}{*}{ Year } & \multicolumn{2}{|c|}{$\begin{array}{l}\text { Anhydrous ammonia } \\
\text { injected }\end{array}$} & \multicolumn{2}{|c|}{$\begin{array}{l}\text { Aqueous ammonia } \\
\text { injected }\end{array}$} & \multirow{2}{*}{$\begin{array}{c}\text { Aqueous } \\
\text { urea } \\
\text { injected }\end{array}$} & \multirow{2}{*}{$\begin{array}{c}\text { 'Nitro- } \\
\text { Chalk' } \\
\text { broadcast } \dagger\end{array}$} & \multicolumn{3}{|c|}{ Cuts taken } \\
\hline & Autumn* & Spring & Autumn* & Spring & & & 1 & 2 & 3 \\
\hline $\begin{array}{l}1966 \\
1967 \\
1968 \\
1969 \\
1970\end{array}$ & $\begin{array}{l}15 \text { Nov. } \\
21 \text { Nov. } \\
14 \text { Nov. } \\
\text { - }\end{array}$ & $\begin{array}{l}2 \mathrm{Mar} . \\
7 \mathrm{Mar} . \\
14 \mathrm{Mar} . \\
28 \mathrm{Mar} . \\
10 \mathrm{Apr} . \ddagger\end{array}$ & $\begin{array}{r}7 \text { Nov. } \\
8 \text { Nov. } \\
13 \text { Nov. }\end{array}$ & $\begin{array}{l}8 \overline{\text { Mar. }} \\
12 \text { Mar. } \\
24 \text { Mar. } \\
19 \text { Mar. }\end{array}$ & $\begin{array}{c}\bar{Z} \\
\overline{-} \\
20 \overline{\mathrm{Mar}}\end{array}$ & $\begin{array}{l}8 \mathrm{Mar} . \\
22 \mathrm{Mar} . \\
15 \mathrm{Mar} . \\
24 \mathrm{Mar} . \\
21 \mathrm{Mar} .\end{array}$ & $\begin{array}{l}17 \text { May } \\
1 \text { June } \\
22 \text { May } \\
4 \text { June } \\
3 \text { June }\end{array}$ & $\begin{array}{l}\text { 4 July } \\
\text { 20 July } \\
9 \text { July } \\
1 \text { Aug. } \\
4 \text { Aug. }\end{array}$ & $\begin{array}{l}5 \text { Sept. } \\
12 \text { Oct. } \\
14 \text { Oct. } \\
15 \text { Oct. } \\
19 \text { Oct. }\end{array}$ \\
\hline
\end{tabular}

* Autumn of previous year.

† Single dressings of 'Nitro-Chalk' and one-third of each divided dressing broadcast on these dates; one-third of divided dressings broadcast after first cut and again after second cut.

$\ddagger 125 \mathrm{~kg} \mathrm{~N} / \mathrm{ha}$ on 19 March.

adjacent to the experiments. We have already described (Widdowson, Penny \& Flint, 1972a) how the commercial ammonia applicator was adapted for the experiments by fitting a burette to it. Appendix Table 1 shows that the amounts injected were close to those intended. The aqueous urea was injected with a similar applicator.

The 'Nitro-Chalk' was always broadcast by hand. In 1966 it was applied to supply the same amounts of $\mathrm{N}$ as anhydrous ammonia, but during 1967-70, when compared with more than one fertilizer, to supply exactly the intended amounts. Appendix Table 1 gives the intended amounts of $\mathrm{N}$ and the actual amounts supplied by each fertilizer in each experiment.

Individual plots were $2.1 \mathrm{~m}$ wide in 1966 and $2.4 \mathrm{~m}$ wide afterwards; they were $15.2 \mathrm{~m}$ long until 1969 when the growth of the grass in spring showed that the anhydrous ammonia injected the previous November had not properly filled the pipes for the first 5-7 m of the plot length. To prevent this happening in 1970 we doubled the length of the plots, injected them all in the same direction of travel and measured yields from the halves injected last.

We used seven tines $30 \mathrm{~cm}$ apart (total width of $2.1 \mathrm{~m}$ ) in 1966 but either six, seven or eight tines $(1 \cdot 8,2 \cdot 1$ or $2.4 \mathrm{~m})$ afterwards, the number varying with the machine and surface conditions. At harvest we discarded a small area at each end of each plot (half of each plot in 1970) and then cut and collected a central swath $1.5 \mathrm{~m}$ wide with an experimental grass harvester (Chalmers \& Kemp, 1962). After weighing the grass, samples were taken from each plot to determine \% dry matter and $\% \mathrm{~N}$ each year and $\% \mathrm{P}$ and $\% \mathrm{~K}$ from 1967 onwards; $\% \mathrm{Mg}$ in grass grown with spring-applied aqueous ammonia and 'Nitro-Chalk' was also determined each year during 1967-70. Table 1 shows when the fertilizers were applied, and when the grass was cut each year.

\section{Field observations}

\section{West Barnfield I experiment, 1966}

The anhydrous ammonia could be injected only 6-8 cm deep and much escaped from the badly sealed slits, especially with the two larger amounts. By 12 April, 'Nitro-Chalk' was giving good growth, but anhydrous ammonia little; the injection slits and the scorched grass along their edges were still obvious. Some of the injection slits were still showing at the second cut (4 July).

\section{Bones Close experiment, 1967}

Both anhydrous and aqueous ammonia were injected 10-12 cm deep, both in autumn and in spring, with little loss. On 31 March the grass was seen to be scorched by 'Nitro-Chalk' supplying 375 or $500 \mathrm{~kg} \mathrm{~N} / \mathrm{ha}$, whereas that injected with either form of ammonia in autumn was growing well. By 17 April, the autumn injection slits were still just visible but the spring ones were very obvious; the tallest grass $(20-22 \mathrm{~cm})$ was given by $500 \mathrm{~kg}$ $\mathrm{N} /$ ha of aqueous ammonia injected in autumn. By 4 July the spring injection slits had opened during the dry weather and the grass near them was brown.

\section{Parklands experiment, 1968}

Both anhydrous and aqueous ammonia were injected $10-12 \mathrm{~cm}$ deep. The soil was very wet in autumn and some tractor wheel-slip damaged the sward. In spring, although the surface was dry, the soil was wet underneath and wheel-slip was still troublesome during injecting. On 29 March it was seen that the grass was scorched by 'NitroChalk' supplying either 500 or $625 \mathrm{~kg} \mathrm{~N} / \mathrm{ha}$, and a little, along the slits, by spring-injected anhydrous ammonia supplying $625 \mathrm{~kg} \mathrm{~N} / \mathrm{ha}$; grass was responding to both forms of ammonia injected in autumn. By 26 April the best growth at each 
amount of $\mathrm{N}$ was from single dressing of 'NitroChalk'.

\section{Appletree experiment, 1969}

Anhydrous ammonia was injected $11-13 \mathrm{~cm}$ deep and the sward was slightly damaged by tractor wheel-slip in autumn. Aqueous ammonia was injected about $10 \mathrm{~cm}$ deep. By 17 April the grass was just beginning to grow but was scorched by 375 and $500 \mathrm{~kg} \mathrm{~N} / \mathrm{ha}$ as 'Nitro-Chalk'; injection slits made in spring opened up during a dry spell at this time. By 23 April the best growth was from autumn-injected aqueous ammonia; grass given $500 \mathrm{~kg} \mathrm{~N} / \mathrm{ha}$ as 'Nitro-Chalk' was still scorched. On 30 June ( $3 \frac{1}{2}$ weeks after first cut) it was seen that injection slits made in spring had again opened in dry weather.

\section{Bones Close experiment, 1970}

All injections were made $10-12 \mathrm{~cm}$ deep. By 5 May the best grass (from 'Nitro-Chalk') was about $25 \mathrm{~cm}$ tall; growth of grass given $500 \mathrm{~kg} \mathrm{~N} / \mathrm{ha}$ as 'Nitro-Chalk' was still slightly checked, and injection slits from anhydrous ammonia tines had opened. By 21 May the best grass lodged, though only 38-45 cm tall; growth from aqueous urea was better than from aqueous ammonia and as good as from single dressings of 'Nitro.Chalk'. On 8 September visual scores showed that growth from aqueous urea was better than from aqueous ammonia and better from either than from single dressings of 'Nitro-Chalk', but not from divided dressings of it.

\section{RESULTS}

\section{Yields}

Appendix Table 2 shows yields from each cut in each experiment, without $N$ and with each amount of each $\mathrm{N}$ fertilizer tested. The commonest method of applying $\mathbf{N}$ for intensively used grass is to broadcast granular fertilizer for each cut, so Table 2 first shows the total annual yields in each experiment from 'Nitro-Chalk' broadcast in equal amounts for the three cuts and then uses each as the standard ( $\equiv 100)$. The total yields from the other $\mathrm{N}$ fertilizers have been expressed as percentages of the yield given by this standard treatment, at each amount of $\mathrm{N}$.

\section{West Barnfield I experiment, 1966}

Yields without $N$ (Appendix Table 2) are from plots which had the injector tines pulled through them; they differed insignificantly from yields from the undisturbed sward and were very small at the first and second cuts and negligible at the third. At the first cut, yields with anhydrous ammonia were only half to two-thirds of those with equiva. lent amounts of 'Nitro-Chalk'; the most ammonia
$(500 \mathrm{~kg} \mathrm{~N} / \mathrm{ha})$ gave less grass (3.14 t/ha) than the least 'Nitro-Chalk' (125 kg N/ha) did (4.46 t/ha).

At the second cut, anhydrous ammonia again gave less grass than the single dressing of 'Nitro. Chalk', but divided dressings of 'Nitro-Chalk' (two-thirds applied) now gave more grass than the single dressings. Yields from anhydrous ammonia and the single dressings of 'Nitro-Chalk' were smaller than at the first cut, but larger with the divided dressings of 'Nitro-Chalk'.

At the third cut, anhydrous ammonia did not increase yields whereas the two larger amounts of spring-applied 'Nitro-Chalk' did, though they in turn were less effective than the divided dressings, which gave up to $3.44 \mathrm{t} / \mathrm{ha}$.

Averaging amounts of $N$, anhydrous ammonia gave $51 \%$ of its total yield at the first cut, $45 \%$ at the second and only $4 \%$ at the third, with corresponding values from 'Nitro-Chalk' applied in one dose, of 49,42 and $9 \%$, so anhydrous ammonia was no more persistent than 'NitroChalk'. The distribution of yield with 'NitroChalk' broadcast in equal amounts for each cut was much better, it gave 35,40 and $25 \%$ of total yield at the first, second and third cuts respectively.

Table 2 shows that total yields with springapplied 'Nitro-Chalk' ranged from 78 to $92 \%$, but with anhydrous ammonia only from 46 to $57 \%$, of that given by an equivalent amount of 'NitroChalk' broadcast for each cut. The small yields with anhydrous ammonia may partly be explained by losses from too shallow injection.

\section{Bones Close experiment, 1967}

Appendix Table 2 shows that this permanent grass yielded as much at the first cut without $N$ $(4 \cdot 67 \mathrm{t} / \mathrm{ha})$ as the ley did in 1966 when given optimum $\mathrm{N}$; there was little benefit in giving this previously grazed grass more than $250 \mathrm{~kg} \mathrm{~N} / \mathrm{ha}$. Our failure to apply the correct amounts of anhydrous ammonia (with one exception, we applied much more than intended) precludes its comparison with equivalent amounts of the other fertilizers, e.g. the large yield shown from $125 \mathrm{~kg} \mathrm{~N} / \mathrm{ha}$ applied in spring was in fact from almost double the amount of $N$ (Appendix Table 1). Autumn. applied aqueous ammonia gave more grass than either spring-applied aqueous ammonia (maximum difference, $1.01 \mathrm{t} / \mathrm{ha}$ ) or spring-applied 'NitroChalk' (maximum difference, $0.92 \mathrm{t} / \mathrm{ha}$ ). There was no benefit from giving more than $83 \mathrm{~kg} \mathrm{~N} / \mathrm{ha}$ as 'Nitro-Chalk' for this first cut.

Typically, the grass grew much less during the second and third cutting periods (June-September was drier than average) than during the first, but even so, the best $\mathrm{N}$ treatment increased yields from 0.79 to $3.22 \mathrm{t} / \mathrm{ha}$ at the second cut and from a negligible 0.29 to $2.86 \mathrm{t} / \mathrm{ha}$ at the third. Autumn. 
Table 2. Total yields ( $t / h a)$ of dry grass each year, from 'Nitro.Chalk' broadcast in equal amounts for each of three cuts ( $\equiv 100 \%$ ) and the relative yields (as a \%) from equivalent amounts of 'Nitro-Chalk' broadcast as a singls dressing in spring, and from several liquid $N$ fertilizers injected either in autumn or in spring at Rothamsted, 1966-70

Yields as a percentage of that from an equivalent amount of 'Nitro-Chalk' broadcast in three equal amounts

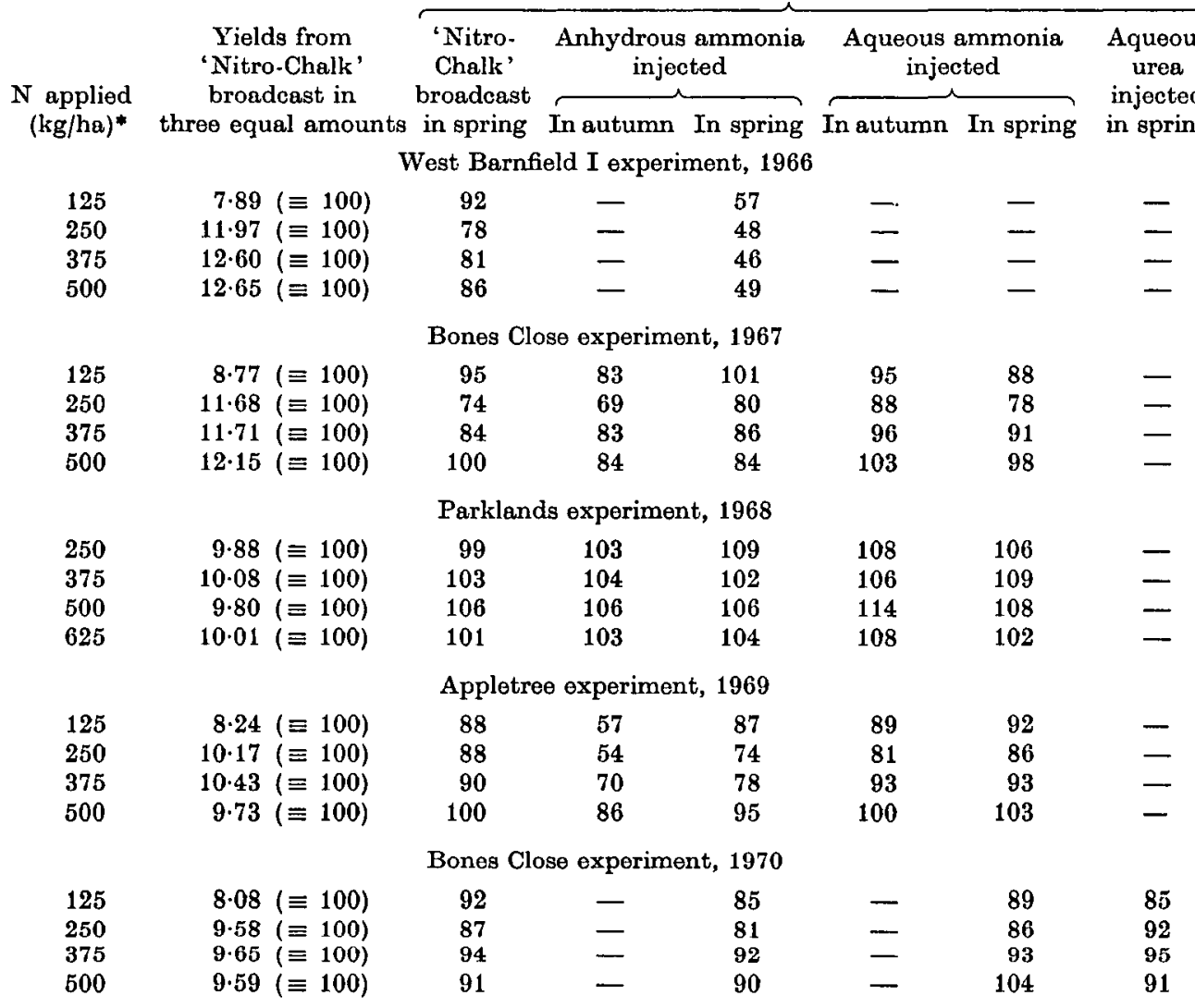

Note: data to be compared horizontally only.

* Intended amounts of N, actual amounts applied are in Appendix Table 1.

and spring-injected aqueous ammonia and single dressings of 'Nitro-Chalk' then all gave similar yields, which were smaller than with 'NitroChalk' broadcast in three equal amounts, except when $500 \mathrm{~kg} \mathrm{~N} / \mathrm{ha}$ was given. Then, a single dose of $N$ (in either form) gave the larger yield at the second cutting, though only spring-applied aqueous ammonia yielded as much at the third cutting. Evidently a very large amount of $N$, even as aqueous ammonia, is needed to give as good a distribution of yield as 'Nitro-Chalk' applied in equal amounts for each cut.

Averaging amounts of $N, 65 \%$ of the total yield given by autumn-injected aqueous ammonia came from the first cut, $23 \%$ from the second and only $12 \%$ from the third; the corresponding values for spring-applied aqueous ammonia were 61,25 and $14 \%$ and for spring-applied 'Nitro-Chalk' 63, 25 and $12 \%$, all very similar. With 'Nitro-Chalk' broadcast for each cut, less of the total yield ( $55 \%$ ) came from the first cut, and more $(20 \%)$ from the third.

Table 2 shows that total yields with a single dose of 'Nitro-Chalk' and with aqueous ammonia were smaller than with 'Nitro-Chalk' broadcast equally for three cuts until $500 \mathrm{~kg} \mathrm{~N} /$ ha was given; then they were similar. Although we applied more $\mathrm{N}$ as anhydrous ammonia than intended (Appendix Table 1) Table 2 shows that the yields from it equalled those from divided dressings of 'NitroChalk' in only one, and those from aqueous ammonia in only two, of eight comparisons. 


\section{Parlclands experiment, 1968}

The anhydrous ammonia was applied much more accurately than in 1967 because it was metered instead of weighed, and yields from it may be compared with those from other fertilizers. At the first cut, yield without $N$ was $2 \cdot 66$ t/ha (Appendix Table 2) and again there was little benefit from giving more than $83 \mathrm{~kg} \mathrm{~N} / \mathrm{ha}$ as 'Nitro-Chalk'. Yields with the two kinds of ammonia differed little (maximum 4.58 t/ha with anhydrous and 4.81 t/ha with aqueous); both gave slightly more grass when injected in autumn than in spring. 'Nitro-Chalk' broadcast in one dose in spring was consistently less good than either sort of ammonia injected the previous autumn and slightly less good than 'Nitro-Chalk' supplying one-third as much $N$ (in three of the four comparisons).

At the second cut, grass not given $\mathbf{N}$ yielded $2 \cdot 28 \mathrm{t} / \mathrm{ha}$ and, although maximum yield always came from applying more than $250 \mathrm{~kg} \mathrm{~N} / \mathrm{ha}$, the extra yield was small. Yields from the two ammonia treatments differed little and were similar to those with a single dressing of 'Nitro-Chalk'.

At the third cut, grass not given $N$ yielded more $(2.95 \mathrm{t} / \mathrm{ha})$ than at either the first or second cuts, and, unusually, $\mathrm{N}$ mostly decreased yields. 'Nitro-Chalk' broadcast equally for three cuts decreased them most. The small responses to more than $250 \mathrm{~kg} \mathrm{~N} /$ ha at the first and second cuts may be explained by the $\mathrm{N}$ content of this soil (judged by $\% \mathrm{~N}$ in grass not given $\mathrm{N}$, Appendix Table 3 ) and the decreases in yield at the third cut by the dull, wet autumn. From April to September there were $247 \mathrm{~h}$ less sunshine than average, and of this deficit $164 \mathrm{~h}$ occurred after $1 \mathrm{July}$. Rainfall from 1 April to 30 September exceeded the average by $115 \mathrm{~mm}$, and of this excess $99 \mathrm{~mm}$ fell after 1 July.

Distribution of total yield was similar with each method of applying $\mathrm{N}$ and ranged from 39 to $43 \%$ at the first cut, from 31 to $34 \%$ at the second and from 25 to $27 \%$ at the third, so in this wet year growth was no more uniform with divided than with single doses of $\mathrm{N}$.

Table 2 shows that, in contrast to the previous 2 years, total yields from broadcasting the 'NitroChalk' in three equal amounts were smaller than from broadcasting it in one dose, which in turn was slightly less good than injecting the $\mathrm{N}$ as either form of ammonia. Total yields from aqueous ammonia were marginally larger than from anhydrous ammonia when injected in autumn, but no different when injected in spring.

\section{Appletree experiment, 1969}

Because of faulty application (see Methods), yields with anhydrous ammonia injected in autumn were not included in the statistical analyses and cannot properly be compared with other yields.

Appendix Table 2 shows that at the first cut the yield without $N$ was $2.49 \mathrm{t} / \mathrm{ha}$, but although $\mathrm{N}$ doubled yield there was little benefit from giving more than $125 \mathrm{~kg} \mathrm{~N} /$ ha. Yields from aqueous ammonia were slightly larger when it was injected in autumn than in spring, and larger than from anhydrous ammonia injected in spring, or from single dressings of 'Nitro-Chalk'. 'Nitro-Chalk' supplying 375 or $500 \mathrm{~kg} \mathrm{~N} / \mathrm{ha}$ scorched the grass and decreased yields, whereas the large doses of ammonia were harmless.

At the second cut the yield without $\mathbf{N}$ declined to $1.37 \mathrm{t} / \mathrm{ha}$. The grass responded up to $500 \mathrm{~kg}$ $\mathrm{N} / \mathrm{ha}$ as spring-injected anhydrous ammonia $(3.83 \mathrm{t} / \mathrm{ha})$, but only three-quarters as much $\mathrm{N}$ as spring-applied aqueous ammonia or 'Nitro-Chalk' was needed to give the same yield. Aqueous ammonia now gave a slightly larger yield when injected in spring than in autumn, but 'NitroChalk' broadcast in equal amounts (two-thirds as much $\mathrm{N}$ ) gave larger yields, except when $500 \mathrm{~kg}$ $\mathrm{N} /$ ha was given.

At the third cut the yield without $N(0.18 \mathrm{t} / \mathrm{ha})$ was the smallest recorded in the five experiments. The maximum yield with anhydrous ammonia was only $0.72 \mathrm{t} / \mathrm{ha}$ and with aqueous ammonia $1.19 \mathrm{t} / \mathrm{ha}$. Yields with 'Nitro-Chalk' applied in three equal doses always exceeded $1 \mathrm{t} / \mathrm{ha}$, but the maximum was only 1.54t/ha. These small yields may be explained by the weather, rainfall being $76 \mathrm{~mm}$ less and sunshine $106 \mathrm{~h}$ less than average, from 1 August to 30 September.

Nitrogen applied in a single dose (averaging amounts and ignoring autumn-applied anhydrous ammonia) gave from 54 to $58 \%$ of total yield at the first cut, from 34 to $38 \%$ at the second and only from 5 to $7 \%$ at the third. Corresponding values for 'Nitro-Chalk' broadcast for each cut were 50,36 and $14 \%$, so divided dressings did little to even out growth.

Table 2 shows that total yields from a single dose of 'Nitro-Chalk' and from aqueous ammonia were smaller than from 'Nitro-Chalk' broadcast in three equal amounts until $500 \mathrm{~kg} \mathrm{~N} / \mathrm{ha}$ was given. Anhydrous ammonia injected in spring also gave smaller yields than divided dressings of 'NitroChalk', but again compared best with it (95\% as good) when $500 \mathrm{~kg} \mathrm{~N} / \mathrm{ha}$ was given.

\section{Bones Close experiment, 1970}

The anhydrous ammonia injector was unsatisfactory at first and had to be repaired. Consequently the anhydrous ammonia was applied three weeks later than the other fertilizers, so yields with it were not statistically analysed with the others. Appendix Table 2 shows that at the first cut yield 
without $N$ was large (4.60 t/ha) and almost identical to that on the same field in 1967, but the response to $N$ was smaller; with each fertilizer, $125 \mathrm{~kg} \mathrm{~N} / \mathrm{ha}$ was enough for maximum yield. Yields with aqueous ammonia were larger than with equivalent amounts of either aqueous urea or 'Nitro-Chalk' and yields with each were larger than with anhydrous ammonia (injected 3 weeks later). The largest dressings of 'Nitro-Chalk' again decreased yields.

At the second cut, yield without $\mathrm{N}$ was only $0.39 \mathrm{t} / \mathrm{ha}$. Although the grass responded to at least $375 \mathrm{~kg} \mathrm{~N} / \mathrm{ha}$, the best yield was only $1.56 \mathrm{t} / \mathrm{ha}$ (with 'Nitro-Chalk'), perhaps because rainfall during June and July was only $72 \mathrm{~mm}$ (44 mm less than average). Differences between the fertilizers were inconsistent, but 'Nitro-Chalk' broadcast on the surface was as effective as injected $\mathrm{N}$ during this dry weather.

At the third cut, yield without $N$ was a negligible $0.27 \mathrm{t} / \mathrm{ha}$, but yields with $\mathrm{N}$ were larger than at the second cut, the only experiment of the five where this happened, perhaps because $115 \mathrm{~mm}$ of rain

Table 3. Total annual yields $(t / h a)$ of dry grass from injecting aqueous ammonia either in autumn or in spring and from broadcasting 'Nitro-Chalk', either in one dose in spring or in equal doses for each of three cuts

Yields are means of 3 years, 1967-9.

\begin{tabular}{|c|c|c|c|c|}
\hline \multirow[b]{2}{*}{$\begin{array}{l}\text { N applied } \\
\text { (kg/ha) }\end{array}$} & \multicolumn{2}{|c|}{$\begin{array}{c}\text { Aqueous ammonia } \\
\text { injected }\end{array}$} & \multicolumn{2}{|c|}{$\begin{array}{c}\text { 'Nitro-Chalk' } \\
\text { broadcast }\end{array}$} \\
\hline & $\underset{\text { autumn }}{\operatorname{In}}$ & $\begin{array}{l}\text { In } \\
\text { spring }\end{array}$ & $\begin{array}{l}\text { All in } \\
\text { spring }\end{array}$ & $\begin{array}{l}\text { One-third } \\
\text { per cut }\end{array}$ \\
\hline 250 & $9 \cdot 72$ & $9 \cdot 45$ & $9 \cdot 14$ & $10 \cdot 58$ \\
\hline 375 & $10 \cdot 53$ & $10 \cdot 44$ & $9 \cdot 86$ & $10 \cdot 74$ \\
\hline 500 & $11 \cdot 14$ & $10 \cdot 86$ & $10 \cdot 76$ & $10 \cdot 56$ \\
\hline Mean & $10 \cdot 46$ & $10 \cdot 25$ & 9.92 & $10 \cdot 63$ \\
\hline
\end{tabular}

fell in August and September, only $11 \mathrm{~mm}$ less than average. Aqueous ammonia gave smaller yields than equivalent amounts of other sorts of $\mathbf{N}$ until $500 \mathrm{~kg} \mathrm{~N} / \mathrm{ha}$ was given, then it gave more. Yields with aqueous urea and with anhydrous ammonia were similar, and slightly larger than with a single dose of 'Nitro-Chalk', but smaller than with 'Nitro-Chalk' broadcast in three equal amounts.

Distribution of total yield differed little between fertilizers; $63-67 \%$ was produced at the first cut, $14-15 \%$ at the second, but $19-23 \%$ at the third.

Table 2 shows that 'Nitro-Chalk' broadcast for each cut gave the largest yield, except when $500 \mathrm{~kg} \mathrm{~N} / \mathrm{ha}$ was given; then aqueous ammonia was best; its yields ranged from $86-104 \%$ of those from divided dressings of 'Nitro-Chalk'. The relative value of 'Nitro-Chalk' broadcast in a single dose ranged from 87 to $94 \%$, of anhydrous ammonia (injected later in spring) from 81 to $92 \%$, and of aqueous urea from 85 to $95 \%$, of the standard divided dressings.

\section{Aqueous ammonia versus 'Nitro-Chalk'}

Table 3 compares total annual yields with aqueous ammonia and with 'Nitro-Chalk' at the three amounts of $\mathrm{N}$ common to the 1967, 1968 and 1969 experiments. With 250 or $375 \mathrm{~kg} \mathrm{~N} / \mathrm{ha}$, the largest yields $(10.58$ and $10.74 \mathrm{t} / \mathrm{ha})$ came from broadcasting 'Nitro-Chalk' in equal amounts for the three cuts and the smallest $(9 \cdot 14$ and $9 \cdot 86 \mathrm{t} / \mathrm{ha})$ from broadcasting it in a single dose in spring; yields with aqueous ammonia were intermediate and were slightly larger with it injected in autumn than in spring. With $500 \mathrm{~kg} \mathrm{~N} / \mathrm{ha}$, however, broadcasting 'Nitro-Chalk' in three equal amounts decreased yields slightly $(10.56 \mathrm{t} / \mathrm{ha})$ and then injecting aqueous ammonia in autumn gave the largest yield (11.14t/ha). Injecting aqueous am. monia in spring consistently gave yields slightly larger than broadcasting 'Nitro-Chalk' in spring,

Table 4. Total yields ( $t / h a)$ of dry grass from three cuts taken from 'uncultivated' swards and from those 'cultivated' either with the anhydrous or with the aqueous ammonia injector

Yields averaged over three amounts of $N(42,83$ and $125 \mathrm{~kg} \mathrm{~N}$ ha/cut all given as 'Nitro.Chalk').

'Cultivation'

\begin{tabular}{lllllll} 
Year & \multicolumn{1}{c}{ None } & $\overbrace{\text { In autumn }}^{\text {With anhydrous }} \begin{array}{c}\text { In spring } \\
\text { ammonia injector }\end{array}$ & $\overbrace{\text { In autumn }}^{\begin{array}{c}\text { With aqueous } \\
\text { ammonia injector }\end{array}}$ & \\
1967 & $10.76( \pm 0.200)$ & 11.07 & 10.67 & 11.21 & 10.35 & \pm 0.282 \\
1968 & $10.20( \pm 0.410)$ & 9.88 & 10.03 & 10.44 & 11.03 & \pm 0.580 \\
Mean & 10.48 & 10.48 & 10.35 & 10.82 & 10.69 & -
\end{tabular}


presumably because it leached less and did not scorch the leaves. So, if the farming system justifies using $375 \mathrm{~kg} \mathrm{~N} / \mathrm{ha}$ or more, this may conveniently be injected in autumn or in spring as a single dose of aqueous ammonia, with little or no loss of yield or efficiency relative to broadcast dressings of 'Nitro-Chalk' repeated through the year.

\section{Effects of slits made by injectors}

In 1967 and 1968 we measured in subsidiary experiments (adjacent to the main ones) the effects of the ammonia injectors on yield. 'Nitro-Chalk' was broadcast to give 42,84 or $125 \mathrm{~kg} \mathrm{~N} / \mathrm{ha}$ per cut on undisturbed plots and on plots 'cultivated' either in autumn or in spring, with either the anhydrous or the aqueous ammonia injector. The 18 treatments were arranged in a single replicate. Table 4 shows that yields were not significantly changed by pulling the injectors through the sward, but the contrasting effects in the two years reflected contrasting soil conditions. Slits were made under good conditions both in autumn 1966 and in spring 1967. Slits made in autumn contracted during winter and expanded less during dry weather in summer than slits made in spring; yields were larger with autumn than with spring 'cultivation'. The soil was very wet in autumn 1967 and wheelslip was more troublesome than in spring 1968; yields were smaller with autumn than with spring 'cultivation'. The broader tines used to inject the anhydrous ammonia damaged the sward more; yields were smaller.

\section{$N$ content of grass}

Appendix Table 3 shows the mean percentages of $\mathrm{N}$ in three cuts of dry grass, the total amounts $(\mathrm{kg} / \mathrm{ha})$ taken up in the three cuts and the apparent percentage recoveries of fertilizer $\mathbf{N}$ by the grass each year.

\section{West Barnfield I experiment, 1966}

Without fertilizer $\mathrm{N}$, the $\% \mathrm{~N}$ in the herbage (1.64) was less than in any of the following experiments even though this ley contained some white clover, so this arable soil supplied less $N(49 \mathrm{~kg} / \mathrm{ha})$ than the grassland soils used afterwards (three under permanent grass, one under a long ley). With anhydrous ammonia, \% $\mathrm{N}$ ranged from 1.68 to only $2 \cdot 13$, but with 'Nitro-Chalk' from 1.83 to 3.12; it differed little between 'Nitro-Chalk' broadcast in spring and equally for the three cuts. With $500 \mathrm{~kg} \mathrm{~N} / \mathrm{ha}$ given as anhydrous ammonia the grass removed only $127 \mathrm{~kg} \mathrm{~N} / \mathrm{ha}$, no more than grass given only $125 \mathrm{~kg} \mathrm{~N} / \mathrm{ha}$ broadcast as 'NitroChalk' in spring. Grass given equal amounts of 'Nitro-Chalk' for each cut removed slightly more $N$ (maximum $383 \mathrm{~kg} / \mathrm{ha}$ ) than grass given it all in spring (maximum $369 \mathrm{~kg} / \mathrm{ha}$ ). The grass apparently recovered only from 13 to $20 \%$ of the $\mathrm{N}$ in anhydrous ammonia, from 51 to $69 \%$ of the $\mathrm{N}$ in a single dose of 'Nitro-Chalk' and from 64 to $73 \%$ of the $\mathbf{N}$ in 'Nitro-Chalk' broadcast in three equal amounts. So, judged by $\% \mathrm{~N}$, uptake of $\mathrm{N}$ and recovery of $\mathrm{N}$, anhydrous ammonia was much less efficient than 'Nitro-Chalk'.

\section{Bones Close experiment, 1967}

Without $\mathrm{N}$, the herbage contained $2.0 \%$ of $\mathrm{N}$ and removed $103 \mathrm{~kg} \mathrm{~N} / \mathrm{ha}$. Although we applied much more anhydrous ammonia than intended, both the $\% \mathrm{~N}$ in the herbage given it and the recovery of the $\mathrm{N}$ by the grass were usually smaller than from aqueous ammonia, which behaved very much like the single dressings of 'Nitro-Chalk'. There was little difference between the efficiency of autumn- and spring-applied aqueous ammonia (maximum \% N, 3.08, maximum uptake of $\mathrm{N}$, $379 \mathrm{~kg} / \mathrm{ha})$, but the largest uptake $(438 \mathrm{~kg} \mathrm{~N} / \mathrm{ha})$ and recovery $(67 \%)$ of $\mathrm{N}$ was by grass given $500 \mathrm{~kg}$ $\mathrm{N} / \mathrm{ha}$ as 'Nitro-Chalk' in spring. 'Nitro-Chalk' applied for each cut was less efficient than a single dose of 'Nitro-Chalk', or of aqueous ammonia, in direct contrast to our results on the arable soil in 1966. The grass apparently recovered only from 20 to $60 \%$ of the $\mathrm{N}$ in anhydrous ammonia, but from 53 to $70 \%$ of the $\mathrm{N}$ in aqueous ammonia and from 44 to $69 \%$ of the $N$ in 'Nitro-Chalk'. So, anhydrous ammonia was less efficient than aqueous ammonia and again less efficient than 'NitroChalk' whether judged by \% $\mathrm{N}$, uptake of $\mathrm{N}$, or recovery of $\mathrm{N}$.

\section{Parklands experiment, 1968}

Without $\mathrm{N}$, both $\% \mathrm{~N}$ in dry grass and uptake of $N(170 \mathrm{~kg} \mathrm{~N} / \mathrm{ha})$ were larger than in any of the other experiments, so this soil was by far the richest in $\mathrm{N}$. Both $\% \mathrm{~N}$ and $\mathrm{N}$ uptake were larger in grass grown with aqueous than with anhydrous ammonia and values for each differed little between autumn and spring injections. The recoveries of $\mathrm{N}$ by grass grown with aqueous ammonia and with a single dose of 'Nitro-Chalk' were similar, but grass given one third of its $\mathbf{N}$ for each cut recovered less than either (both as \% and as uptake). Percentage recoveries of $N$ were less than in 1966 or 1967 , most probably because the grass responded less in the dull wet summer. They ranged from 28 to $41 \%$ with anhydrous ammonia, 32 to $50 \%$ with aqueous ammonia, 32 to $47 \%$ with 'Nitro-Chalk' in a single dose, and from 28 to $34 \%$ with 'NitroChalk' applied in three equal doses. Judged by \% $\mathrm{N}$ in grass, uptake and recovery of $\mathrm{N}$, aqueous ammonia and spring-applied 'Nitro-Chalk' were again more efficient than anhydrous ammonia, but unusually 'Nitro-Chalk' applied in three equal doses was not. 


\section{Appletree experiment, 1969}

Without $\mathrm{N}$, the herbage from this long ley contained $1.71 \% \mathrm{~N}$ and removed $65.4 \mathrm{~kg} \mathrm{~N} / \mathrm{ha}$, only slightly more than the short ley did in $\mathbf{1 9 6 6 .}$ Less $\mathbf{N}$ was recovered from anhydrous ammonia injected in autumn than from any other treatment (presumably because the applicator did not work properly). Except with $125 \mathrm{~kg} \mathrm{~N}$, grass given aqueous ammonia in spring contained more $\mathrm{N}$ and recovered more of that given than grass given anhydrous ammonia in spring, though no more than from a single dressing of 'Nitro-Chalk'. Also, aqueous ammonia was as effective when injected in autumn as in spring, when judged in either way; the recovery of it ranged from $67 \%$ of $125 \mathrm{~kg} \mathrm{~N} / \mathrm{ha}$ to $44 \%$ of $500 \mathrm{~kg} \mathrm{~N} / \mathrm{ha}$. More $\mathrm{N}$ was recovered from three equal amounts of 'Nitro-Chalk' than from a single dose, except when $500 \mathrm{~kg} \mathrm{~N} / \mathrm{ha}$ was tested, and the recovery of these divided dressings ranged from $69 \%$ of the smallest to $40 \%$ of the largest.

\section{Bones Close experiment, 1970}

Without $\mathrm{N}$, the herbage contained $1.97 \% \mathrm{~N}$ and removed $92 \mathrm{~kg} \mathrm{~N} / \mathrm{ha}$, only a little less than in 1967 . With $\mathrm{N}, \% \mathrm{~N}$ differed little between fertilizers and ranged from 2.31 with $125 \mathrm{~kg} \mathrm{~N} / \mathrm{ha}$ to 3.28 with $500 \mathrm{~kg} \mathrm{~N} / \mathrm{ha}$. Grass took up slightly, but consistently more $\mathbf{N}$ from aqueous urea than from anhydrous ammonia and again slightly more than from aqueous ammonia or 'Nitro-Chalk' until $500 \mathrm{kgN} / \mathrm{ha}$ was given, then it was not quite as efficient. So, judged by uptake, urea injected like this was as efficient as the other fertilizers, in direct contrast to its smaller value when surface applied (Cooke, 1964). The very large recovery $(96 \%)$ from the smallest amount of anhydrous ammonia is suspect, because although the meter showed that wo had applied only $86 \mathrm{~kg} \mathrm{~N} / \mathrm{ha}$ (Appendix Table 1), we later found that the pump was not working properly.

\section{The recovery of $N$ from aqueous ammonia and 'Nitro-Chalk'}

Table 5 shows $\% \mathrm{~N}$, removal (kg/ha) and \% recovery of $\mathrm{N}$, averaged over the three experiments in which aqueous ammonia was injected both in autumn and in spring. At the first cut, $\% \mathrm{~N}$ was largest with a single spring dressing of 'NitroChalk', and larger with aqueous ammonia injected in spring than in autumn, but at the second and third cuts differed little. The $\% \mathrm{~N}$ in grass given equal amounts of 'Nitro-Chalk' for each cut was smaller at the first cut, but larger at the second and

Table 5. The percentage of $N$ in, and the amount of $N$ removed by, each of three cuts of grass grown without $N$ fertilizer and with either aqueous ammonia or 'Nitro-Chalk', and the apparent percentage recoveries of $N$ from these two fertilizers

Mean of 3 years, 1967-9.

\begin{tabular}{|c|c|c|c|c|c|c|c|c|c|c|}
\hline \multirow{3}{*}{$\begin{array}{l}\text { Cut... } \\
\text { N applied (kg/ha) } \\
\text { None }\end{array}$} & \multicolumn{3}{|c|}{$\begin{array}{l}\text { Percentage of } \mathrm{N} \\
\text { in dry grass }\end{array}$} & \multicolumn{3}{|c|}{$\begin{array}{l}\text { Amounts (kg/ha) } \\
\text { of } \mathrm{N} \text { recovered }\end{array}$} & \multicolumn{4}{|c|}{$\begin{array}{l}\text { Percentage of total amount of } \\
\text { fertilizer-N apparently recovered in }\end{array}$} \\
\hline & 1st & 2nd & 3 rd & 1st & 2nd & $3 \mathbf{r d}$ & 1st & 2nd & 3 rd & $\begin{array}{l}\text { Total of } \\
3 \text { cuts }\end{array}$ \\
\hline & 1.80 & 1.84 & $2 \cdot 20$ & $58 \cdot 4$ & $26 \cdot 6$ & $27 \cdot 9$ & - & - & - & - \\
\hline \multicolumn{11}{|c|}{ As aqueous ammonia injected in autumn } \\
\hline 250 & $2 \cdot 79$ & $2 \cdot 23$ & $2 \cdot 18$ & $145 \cdot 1$ & 68.7 & $32 \cdot 2$ & 34 & 16 & 2 & 52 \\
\hline 375 & $3 \cdot 05$ & 2.77 & $2 \cdot 64$ & $167 \cdot 2$ & $90 \cdot 5$ & $46 \cdot 3$ & 28 & 17 & 5 & 50 \\
\hline 500 & $3 \cdot 23$ & 3.03 & $3 \cdot 09$ & $179 \cdot 5$ & $101 \cdot 1$ & $70 \cdot 2$ & 23 & 14 & 8 & 46 \\
\hline \multicolumn{11}{|c|}{ As aqueous ammonia injected in spring } \\
\hline 250 & $2 \cdot 90$ & $2 \cdot 28$ & $2 \cdot 28$ & $146 \cdot 8$ & $68 \cdot 3$ & $34 \cdot 1$ & 35 & 16 & 2 & 54 \\
\hline 375 & $3 \cdot 19$ & $2 \cdot 70$ & $2 \cdot 43$ & $164 \cdot 6$ & 92.6 & $44 \cdot 5$ & 28 & 18 & 4 & 50 \\
\hline 500 & $3 \cdot 45$ & $3 \cdot 17$ & $2 \cdot 96$ & $176 \cdot 8$ & 107.8 & $69 \cdot 8$ & 23 & 16 & 8 & 47 \\
\hline \multicolumn{11}{|c|}{ As 'Nitro-Chalk' broadcast in spring } \\
\hline 250 & $3 \cdot 11$ & $2 \cdot 22$ & $2 \cdot 31$ & $149 \cdot 7$ & $66 \cdot 2$ & $31 \cdot 2$ & 36 & 16 & 1 & 53 \\
\hline 375 & $3 \cdot 37$ & $2 \cdot 67$ & $2 \cdot 67$ & $161 \cdot 7$ & $88 \cdot 5$ & $45 \cdot 1$ & 27 & 16 & 5 & 48 \\
\hline 500 & $3 \cdot 86$ & $3 \cdot 17$ & $3 \cdot 03$ & $197 \cdot 3$ & $113 \cdot 1$ & $63 \cdot 3$ & 28 & 17 & 7 & 52 \\
\hline \multicolumn{11}{|c|}{ As 'Nitro.Chalk' broadcast in three equal amounts (one per cut)* } \\
\hline 250 & $2 \cdot 36$ & $2 \cdot 40$ & $2 \cdot 54$ & $123 \cdot 8$ & $78 \cdot 3$ & $52 \cdot 3$ & 78 & 62 & 29 & 56 \\
\hline 375 & $2 \cdot 22$ & 3.02 & $3 \cdot 12$ & 112.9 & $104 \cdot 3$ & $68 \cdot 5$ & 43 & 62 & 33 & 46 \\
\hline 500 & $2 \cdot 65$ & $3 \cdot 12$ & $3 \cdot 09$ & $137 \cdot 2$ & $100 \cdot 2$ & 63.7 & 47 & 44 & 21 & 38 \\
\hline
\end{tabular}

* Apparent recoveries from 'Nitro-Chalk' broadcast in three equal amounts calculated as \% of that given for each cut. 
Table 6. The percentages of $P, K$ and $M g$ (in dry grass) at each of three cuts and the total amounts removed by grass given either aqueous ammonia or 'Nitro-Chulk' in spring

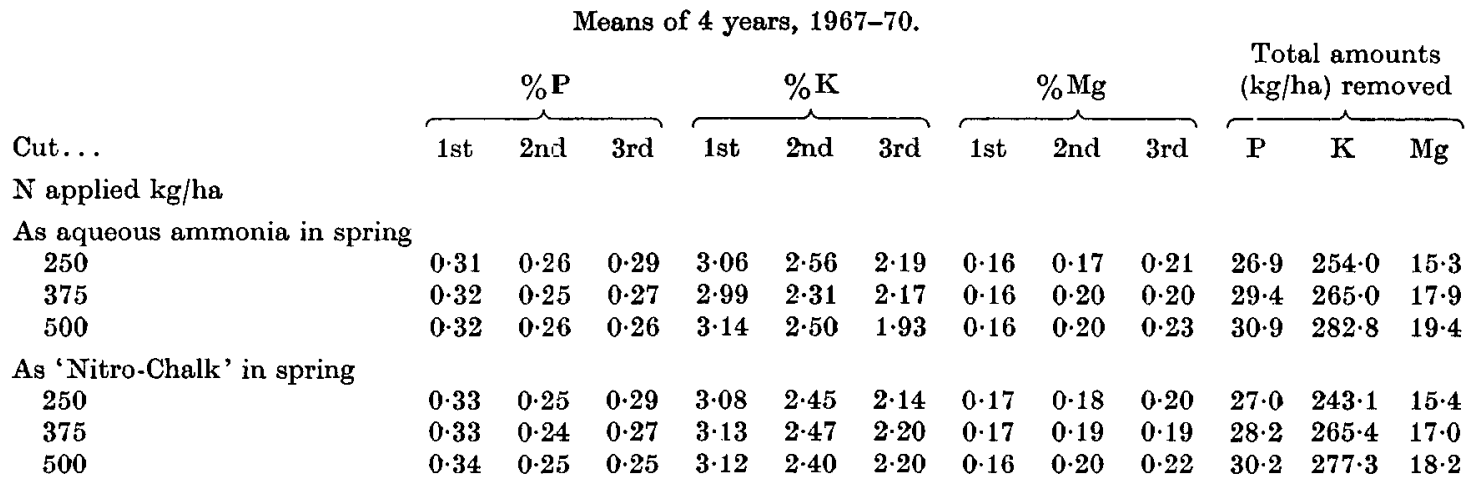

third cuts than in grass given spring dressings of $\mathrm{N}$, except when $500 \mathrm{~kg} \mathrm{~N} /$ ha was given. $\mathrm{N}$ in grass was increased by giving $\mathrm{N}$ fertilizer from 1.80 to $3.86 \% \mathrm{~N}$ in dry matter at the first cut, from 1.84 to 3.17 at the second, and from 2.20 to 3.12 at the third.

Table 5 also shows how similar were the amounts of $\mathrm{N}$ removed by grass given aqueous ammonia, either in autumn or in spring and from aqueous ammonia at either time and the single dose of 'Nitro-Chalk'. The largest difference was only about $20 \mathrm{~kg} \mathrm{~N} / \mathrm{ha}$ and that in grass given 500 $\mathrm{kg} \mathrm{N} /$ ha as 'Nitro-Chalk' for the first cut.

Table 5 also shows that the apparent percentage recovery of $\mathrm{N}$ from fertilizer by individual cuts was similar from equivalent amounts of aqueous ammonia and 'Nitro-Chalk' (single dose) and that two-thirds of the recovery from $250 \mathrm{~kg} \mathrm{~N} / \mathrm{ha}$ and half of the recovery from $500 \mathrm{~kg} \mathrm{~N} / \mathrm{ha}$ was at the first cut. Recovery from 'Nitro-Chalk' applied in three equal doses was slightly more uniform. The apparent recovery of the applied $\mathrm{N}$ in all three cuts ranged from 46 to $54 \%$ with aqueous ammonia, 48 to $53 \%$ with 'Nitro-Chalk' in a single dose and 38 to $56 \%$ with 'Nitro-Chelk' in three equal doses. So the smallest and the largest recovery was from the divided dressings of $\mathrm{N}$.

\section{$P, K$ and $M g$ contents}

From 1967 to $1970 \% \mathrm{Mg}$ was determined in the dry grass to see if it differed when $\mathrm{N}$ was given in spring wholly (aqueous ammonia) rather than partly ('Nitro-Chalk') in the ammonium form. Table 6 shows that it did not, but that it was smallest (about $0.16 \%$ ) at the first and largest (about $0.21 \%$ ) at the third cut, and tended to increase slightly with increasing amounts of $N$ at the second and third cuts, but not at the first. Amounts (kg/ha) of $\mathrm{Mg}$ removed by the three cuts ranged from 15.3 with $250 \mathrm{~kg} \mathrm{~N} /$ ha to 19.4 with $500 \mathrm{~kg}$ $\mathrm{N} / \mathrm{ha}$.

Table 6 also shows that $\% \mathrm{P}$ and $\% \mathrm{~K}$ in the grass differed little with either form or amount of N. Percentage $P$ was slightly larger (about $0.32 \%$ ) at the first than at the second or third cuts. Percentage $K$ was also largest (about $3 \cdot 1 \%$ ) at the first cut and smallest (about $2 \cdot 1 \%$ ) at the third cut, in direct contrast to \% Mg. The table also shows that amounts of $P$ and $K$ removed in three cuts differed little between aqueous ammonia and 'Nitro-Chalk' and ranged from about $27 \mathrm{~kg} \mathrm{P}$ and $250 \mathrm{~kg} \mathrm{~K} / \mathrm{ha}$ when $250 \mathrm{~kg} \mathrm{~N} / \mathrm{ha}$ was given, to about $30 \mathrm{~kg} P$ and $280 \mathrm{~kg} \mathrm{~K} / \mathrm{ha}$ when $500 \mathrm{~kg} \mathrm{~N} / \mathrm{ha}$ was given.

\section{DISCUSSION}

Since we started our experiments several authors have reported work with anhydrous ammonia, but few with aqueous ammonia for grassland. Most experiments showed that anhydrous ammonia gave smaller yields of grass than solid $\mathbf{N}$ fertilizers. Typical results were presented at a Symposium at the National College of Agricultural Engineering, Silsoe, Bedford, in 1970. Whitear reported experi. ments by Fisons Ltd., showing that anhydrous ammonia was only 30-95\% as good as ammonium nitrate, as ammonium sulphate or as ammonium sulphate nitrate, for increasing yields of dry matter and $\mathrm{N}$ uptake. $\mathrm{He}$ stated that some of the ineffi. ciency may have been due to loss of gas at injection, to the decomposition of ammonium nitrite if formed at the point of injection and by damage to the sward on heavy soils. At the same Symposium, Herriott et al. showed that, in the east of Scotland, anhydrous ammonia produced 78-97\% as much dry matter as solid $\mathrm{N}$ fertilizer; the injection knives often severely damaged the short-term leys common there, but not old swards. In our experi- 
monts ammonia gas escaped during injection very obviously in 1966, and though little escaped in later years, some scorch showed later, along the slits. In subsidiary experiments (Table 4) the anhydrous ammonia injector damaged the sward enough to decrease yields (non-significantly) in three of four comparisons.

Reid \& Castle (1970) found that in south-west Scotland single applications of anhydrous ammonia gave less yield than ammonium nitrate repeatedly broadcast during the growing season. Because they minimized ammonia loss and sward damage by using a hand injector, they suggested that anhydrous ammonia was inferior because of the slower uptake of $\mathrm{N}$ from it, particularly in spring, and that uptake might be improved by winter or early spring injection. We compared autumn and spring applied anhydrous ammonia for 3 years, but accurately only in 1968 when they were equally effective. Aqueous ammonia was applied accurately in all 3 years and total yields were similar with autumn and with spring injection in each. Yields at the first cut usually were larger with the autumn applications than with the spring, though the amounts of $\mathrm{N}$ recovered were not. So, the larger yields with autumn injection were most probably because nitrification and $\mathbf{N}$ uptake in spring were earlier, which would support Reid \& Castle's suggestion.

Gasser, Blakemore \& Flint (1972) used a small hand-injector to apply anhydrous ammonia in several injection patterns (rows and square or nearly square spacing) and concluded that, although injection in rows was the most efficient method of application, the consequence of concentrating the ammonia in bands $30 \mathrm{~cm}$ apart (the usual spacing) was direct damage to the grass along the lines of injection, thus diminishing yield. Large amounts of anhydrous ammonia (500 kg N/ha) scorched the grass along the slits in our experiments, but equivalent amounts of 'Nitro-Chalk' scorched more grass more uniformly, so the expansion of the injection slits during dry weather and the consequent drying, may have decreased yield as much as scorch did.

The inefficiency of anhydrous ammonia in our experiments therefore seems to have been due to a combination of (1) loss of gas during injection, (2) scorching of the grass along the lines of injection, (3) mechanical damage by the injector tines, (4) loss of moisture along the injection slits during dry weather, and (5) a slower and smaller recovery of $\mathrm{N}$.

Exceptionally, Williams \& Cooke (1972) found anhydrous ammonia to be as efficient as 'NitroChalk' for grass on the sandy clay soil at Saxmundham, Suffolk. This was undoubtedly because much of the nitrate $\mathrm{N}$ from the 'Nitro-Chalk' was leached by heavy and at times intense rain, which fell shortly after they had both been applied in March 1969 (Williams, 1971). Leaching of nitrate-N may partly explain why anhydrous ammonia was at least as good as 'Nitro-Chalk' in our 1968 experiment; but even then it was still slightly less good than aqueous ammonia. Whitear (1970) also found that anhydrous ammonia compared best with solid $\mathbf{N}$ fertilizer when rainfall was either well distributed or above average, underlining the risks of losing nitrate- $\mathrm{N}$ by leaching in spring.

There are fewer published results of experiments with aqueous ammonia to compare with ours. Cowling (1968) found single applications of aqueous arnmonia as good as single dressings of ammonium nitrate, but not as good as divided dressings for ryegrass, agreeing broadly with our results. Hodgson \& Draycott (1968) concluded that aqueous ammonia was as effective as ammonium sulphate or as a solution of ammonium nitrate and urea for grass. There were several reasons why aqueous ammonia was a better $N$ fertilizer for grass than anhydrous ammonia in our experiments. We found (1) that aqueous ammonia was easier to inject satisfactorily into our 'Clay-with-Flints' soil than anhydrous ammonia and the absence of smell of ammonia over the slits after injection showed that it was well sealed, (2) that the aqueous ammonia injector knives did good rather than harm to the sward (Table 4), and (3) most importantly, that more $N$ was recovered from aqueous than from anhydrous ammonia.

Aqueous urea and aqueous ammonia differed little in performance when injected in the same way in 1970. However, one experiment was not sufficient for a proper assessment of aqueous urea for grass, though we showed (1972) that it was equally as good as aqueous ammonia for barley.

We obtained no evidence that injected $\mathbf{N}$ gave more grass than broadcast $\mathbf{N}$ did during dry weather, and none to justify giving more than $375 \mathrm{~kg} \mathrm{~N} / \mathrm{ha}$. Grass given $375 \mathrm{~kg} \mathrm{~N} / \mathrm{ha}$ removed approximately $3 \mathrm{~kg}$ of $\mathrm{P}, 26 \mathrm{~kg}$ of $\mathrm{K}$ and $2 \mathrm{~kg}$ of $\mathrm{Mg}$ per tonne of dry matter produced; these removals of $P$ and $K$ agree closely with those by short duration leys at Rothamsted which were given a total of $340 \mathrm{~kg} \mathrm{~N} / \mathrm{ha}$ for three cuts (Widdowson, 1968). It is usually considered that for stock fed largely on grass the dry matter should contain at least $0.2 \% \mathrm{Mg}$ as a safeguard against hypomagnesaemia. Table 6 shows that, on average, grass at the first cut contained less, and at the second and third cuts no more than this minimum amount.

We thank D. M. Ramsay, Fertilizer Placement Ltd., Navenby, Lincoln, for adapting his injector to inject the aqueous ammonia and for designing the one used to inject the aqueous urea, and 
T. A. Marriott, Calor Agriculture Itd., for providing the anhydrous ammonia injector. We also thank J.H. A. Dunwoody for statistical analyses,
E. Bird, R. J. Avery and H. A. Smith for chemical analyses, and all others who helped with the experiments.

\section{REFERENCES}

Chalmers, G. R. \& Kemp, D. C. (1962). A harvester for herbage plots. J. agric. Engng Res. 7, 64.

Cooke, G. W. (1964). Nitrogen fertilisers. Proc. Fertil. Soc. no. 80.

Cowting, D. W. (1968). Ammonia as a source of nitrogen for grass swards. $J$. Br. Grassld Soc. 23, 53-60.

Gasser, J. K. R., Blakemore, M. \& Flint, R. C. (1972). Experiments on the use of anhydrous ammonia for grass. $J$, agric. Sci., Camb. 78, 193-201.

Herriott, J. B. D., Tribe, A. J., Crooks, P. \& EDwards, A. (1970). Anhydrous liquified ammonia for grassland. In Proceedings of a Symposium on Anhydrous Ammonia, pp. 55-60. National College of Agricultural Engineering, Silsoe, Bedford.

Hodgson, D. R. \& Draycott, A. P. (1968). Aqueous ammonia compared with other nitrogenous fertilizers as solids and solutions on grass. J. agric. Sci., Camb. 71, 195-203.

Hunter, F. \& Jarvis, G. F. (1953). Ammonia gas as a fertilizer. Agriculture, Lond. 60, 275-7.

JAMESON, H. R. (1959). Liquid nitrogenous fertilizers. J. agric. Sci., Camb. 53, 33-8.

REID, D. \& CaStLe, M. E. (1970). A comparison of the effects of anhydrous ammonia and a solid ammonium nitrate fertilizer on herbage production from a pure perennial ryegrass sward. $J$. agric. Sci., Camb. 75, 523-32.

Whitear, J. D. (1970), Levington experiments on anhydrous ammonia for grass and arable crops. In Proceedings of Symposium on Anhydrous Ammonia, pp. 39-54. National College of Agricultural Engineering, Silsoe, Bedford.

Widdowson, F. V. (1968). Why starve grass? Dairy Farmer, Feb. 1968.

Widdowson, F. V. \& Pensy, A. (1970). Anhydrous ammonia - yields and recoveries by spring wheat. In Proceedings of a Symposium on Anhydrous Ammonia, pp. 61-6. National College of Agricultural Engineering, Silsoe, Bedford.

Widdowson, F. V., Penny, A. \& Flint, R. C. (1972a). Results from an experiment comparing aqueous ammonia and 'Nitro-Chalk' for grazed grass. $J$. agric. Sci., Camb. 79, 341-8.

Widdowson, F. V., Penny, A. \& Fuist, R. C. (1972b). Results from barley experiments comparing aqueous ammonia and aqueous urea with ammonium nitrate, and also liquid with granular NPK fertilizers. $J$. agric. Sci., Camb. 79, 349-61.

Wriliams, R. J. B. \& Cooke, G. W. (1972). Experiments on herbage crops at Saxmundham, 1967-71. Rep. Rothamsted exp. Stn for 1971, part 2, pp. 95-121.

Wirliams, R. J. B. (1971). The chemical composition of water from land drains at Saxmundham and Woburn, and the influence of rainfall upon nutrient losses. Rep. Rothamsted exp. Stn for 1970, part 2, pp. 36-67.

\section{Appendix Table 1. The intended and actual amounts (kg/ha) of $N$ applied as each fertilizer in each experiment, 1966-70}

Experiments

\begin{tabular}{|c|c|c|c|c|c|c|c|c|c|c|c|c|c|c|c|c|c|}
\hline Exporiment... & \multicolumn{2}{|c|}{$\begin{array}{c}\text { West } \\
\text { Barnfield }\end{array}$} & \multicolumn{4}{|c|}{ Bones Close } & \multicolumn{4}{|c|}{ Parklands } & \multicolumn{4}{|c|}{ Appletree } & \multicolumn{3}{|c|}{ Bones Close } \\
\hline Year... & \multicolumn{2}{|c|}{1966} & \multicolumn{4}{|c|}{1967} & \multicolumn{4}{|c|}{1968} & \multicolumn{4}{|c|}{1969} & \multicolumn{3}{|c|}{1970} \\
\hline \multirow{2}{*}{$\begin{array}{l}\text { Fertilizer } \\
\text { Intended } \\
\text { amount }\end{array}$} & \multirow{2}{*}{\multicolumn{2}{|c|}{$\begin{array}{l}\text { An. N.C } \\
\text { (spring) }\end{array}$}} & \multirow{2}{*}{\multicolumn{2}{|c|}{$\begin{array}{c}\text { An. Aq. } \\
\text { (autumn)* }\end{array}$}} & \multicolumn{2}{|c|}{$\begin{array}{c}\text { An. Aq } \\
\text { (spring) }\end{array}$} & \multirow{2}{*}{\multicolumn{2}{|c|}{ An. Aq. }} & \multicolumn{2}{|c|}{$\underset{\text { (spring) }}{\text { An. Aq. }}$} & \multicolumn{2}{|c|}{$\begin{array}{l}\text { An. Aq. } \\
\text { (autumn)* }\end{array}$} & \multicolumn{2}{|c|}{$\underset{\text { (spring) }}{\text { An. Aq. }}$} & \multirow{2}{*}{\multicolumn{2}{|c|}{ An. Aq. }} & \multirow[t]{2}{*}{ U } \\
\hline & & & & & & Actu & & & appli & & & & & & & & \\
\hline 125 & 125 & 125 & 152 & 116 & 238 & 127 & - & - & - & - & 127 & 126 & 120 & 131 & 86 & 122 & 121 \\
\hline 250 & 306 & 306 & 285 & 249 & 351 & 254 & 262 & 275 & 257 & 262 & 262 & 246 & 266 & 244 & 256 & 247 & 251 \\
\hline 375 & 370 & 370 & 418 & 375 & 402 & 389 & 366 & 389 & 360 & 374 & 378 & 393 & 376 & 368 & 370 & 367 & 37 \\
\hline & 491 & 491 & 684 & 520 & 489 & 506 & 499 & 531 & 523 & 495 & 498 & 499 & 497 & 529 & 506 & 511 & 511 \\
\hline 625 & - & - & - & - & - & - & 601 & 649 & 609 & 611 & - & - & - & - & - & - & - \\
\hline
\end{tabular}

An. $=$ anhydrous ammonia. Aq. $=$ aqueous ammonia. $\mathrm{N} \cdot \mathrm{C}=$ 'Nitro.Chalk'. $\mathrm{U}=$ aqueous urea.

* Autumn of previous year. 


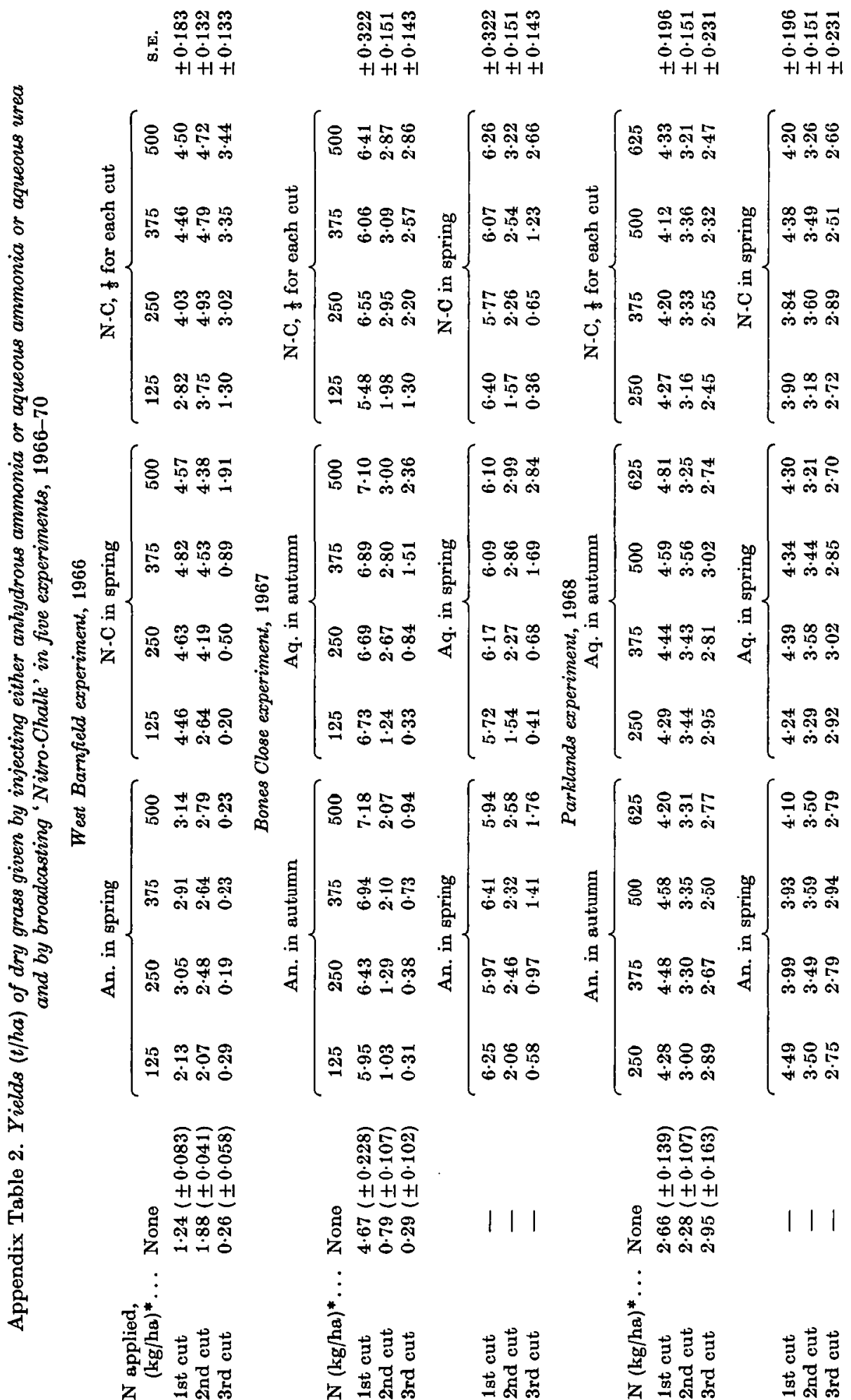




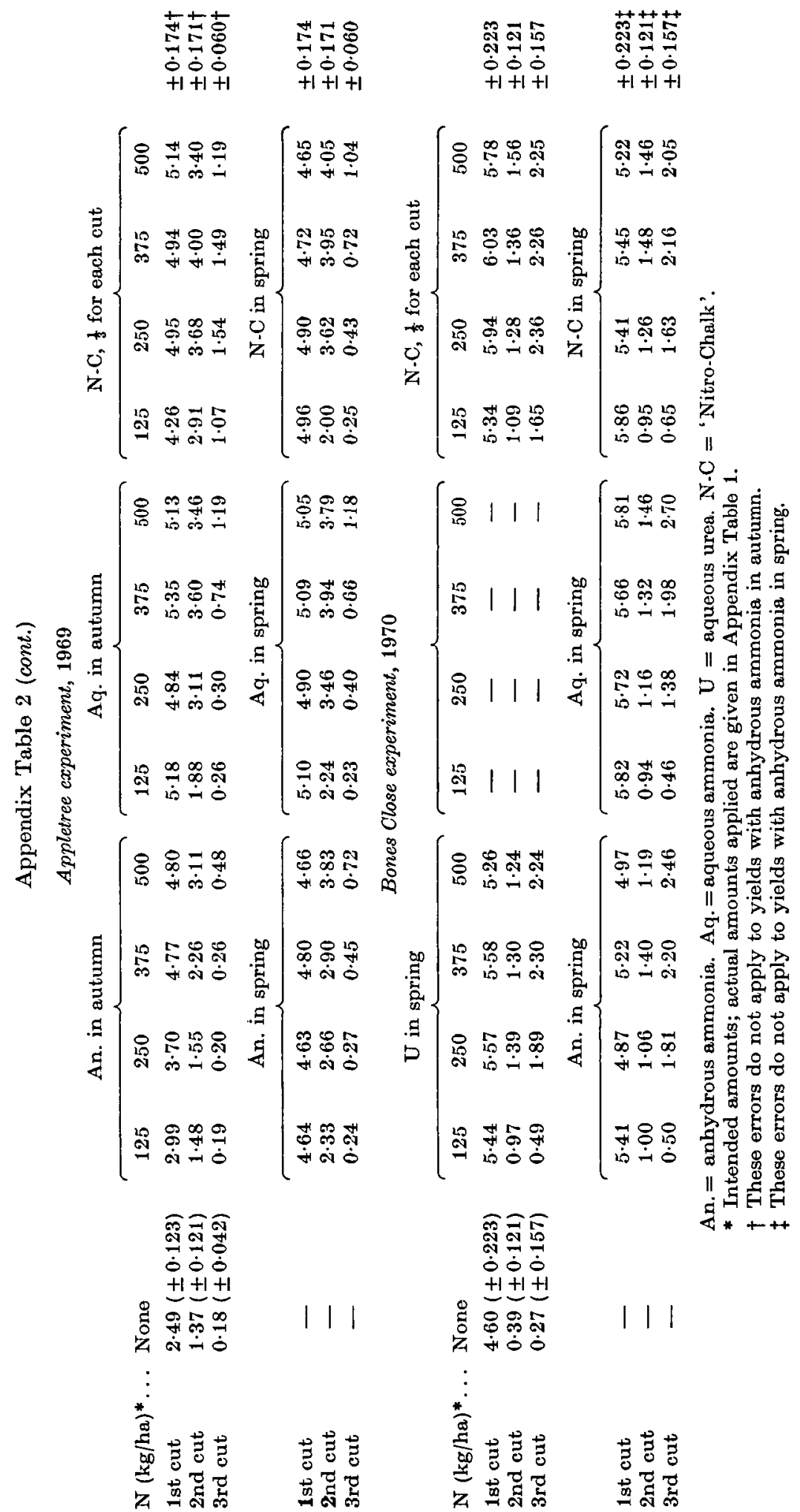




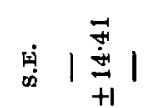

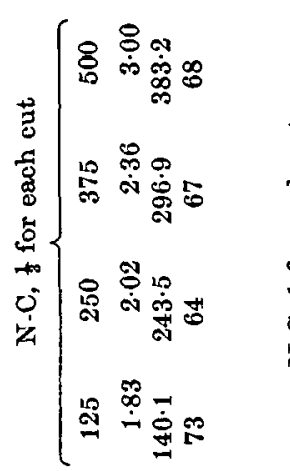

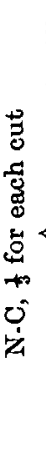
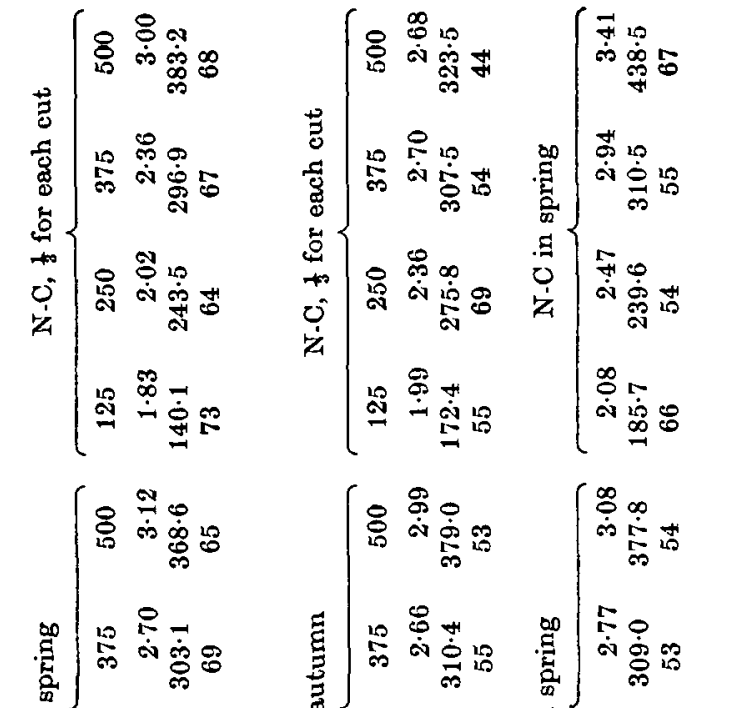

$\because$.

$\{0$

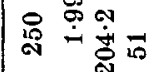

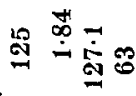

(융

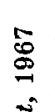

$\stackrel{\Xi}{\square}$

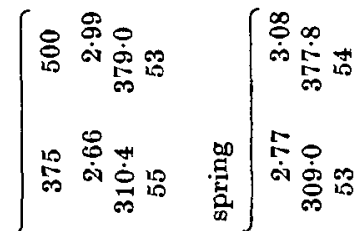

$\Xi$

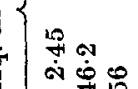

हैँ

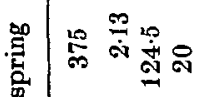

.

过

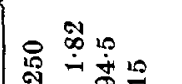

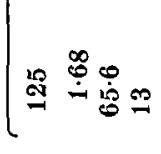

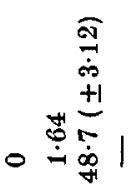

के

o.

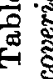

ํ.

$\frac{0}{4}$

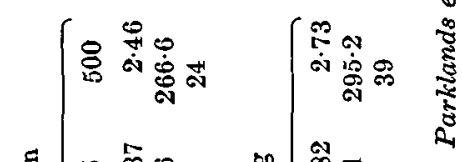

है

马े

政

4

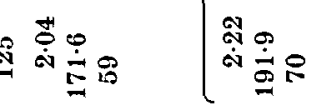
䚁 $\exists$. 兘 iิ 4 (1)

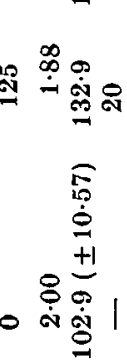

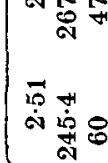

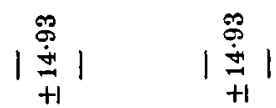

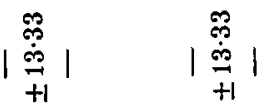

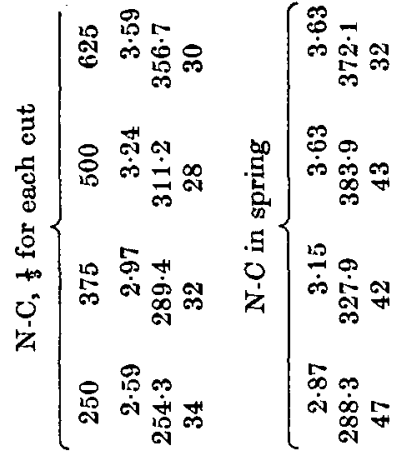

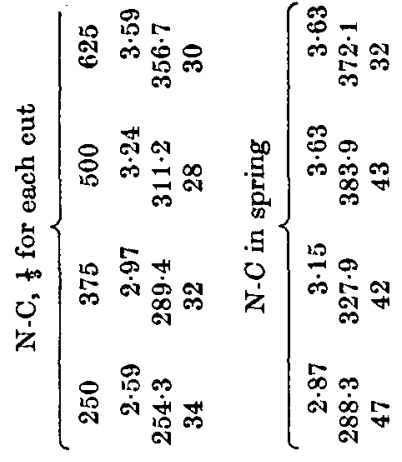

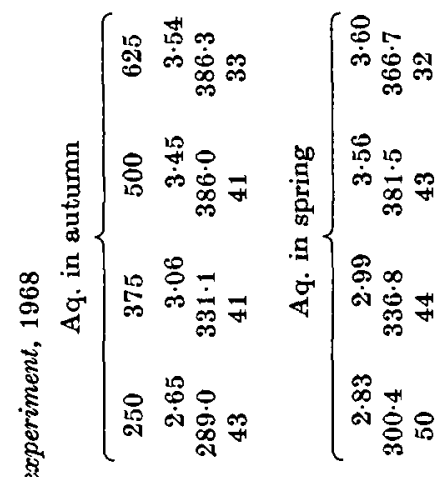

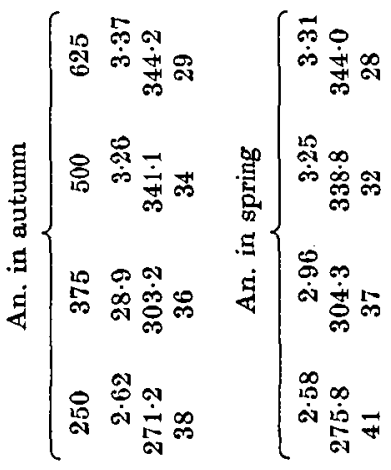
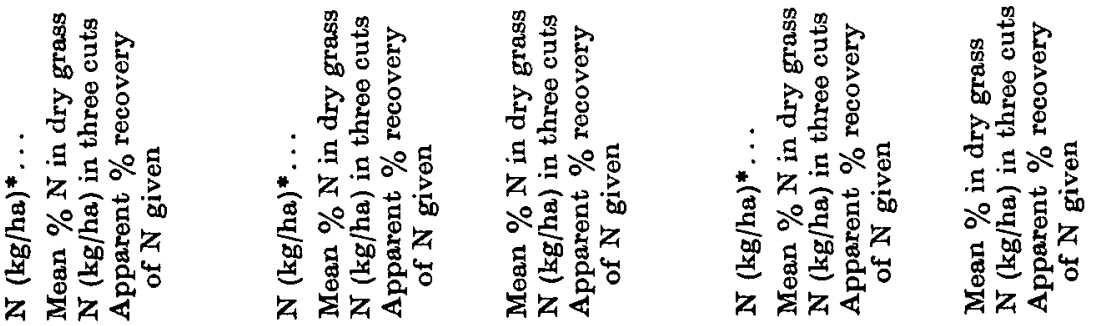


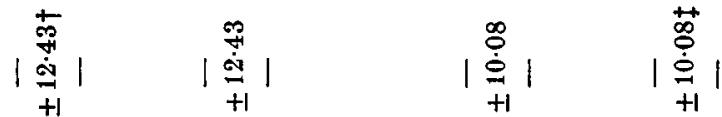

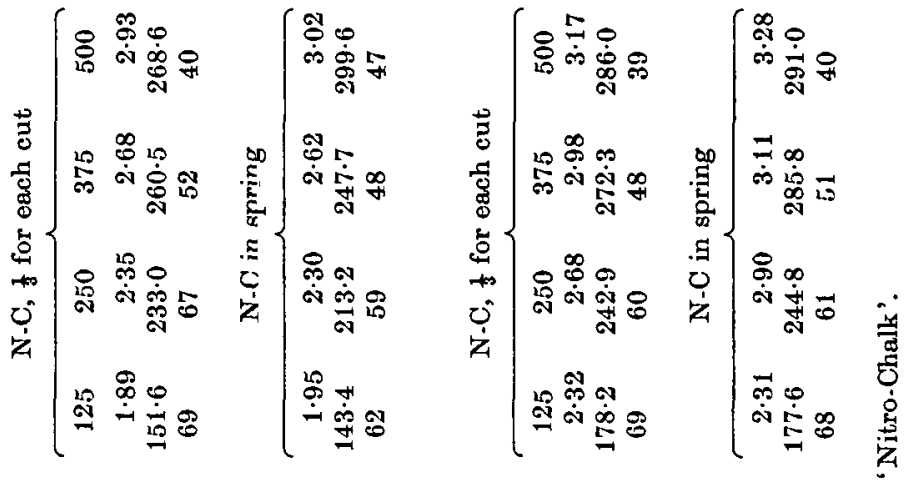

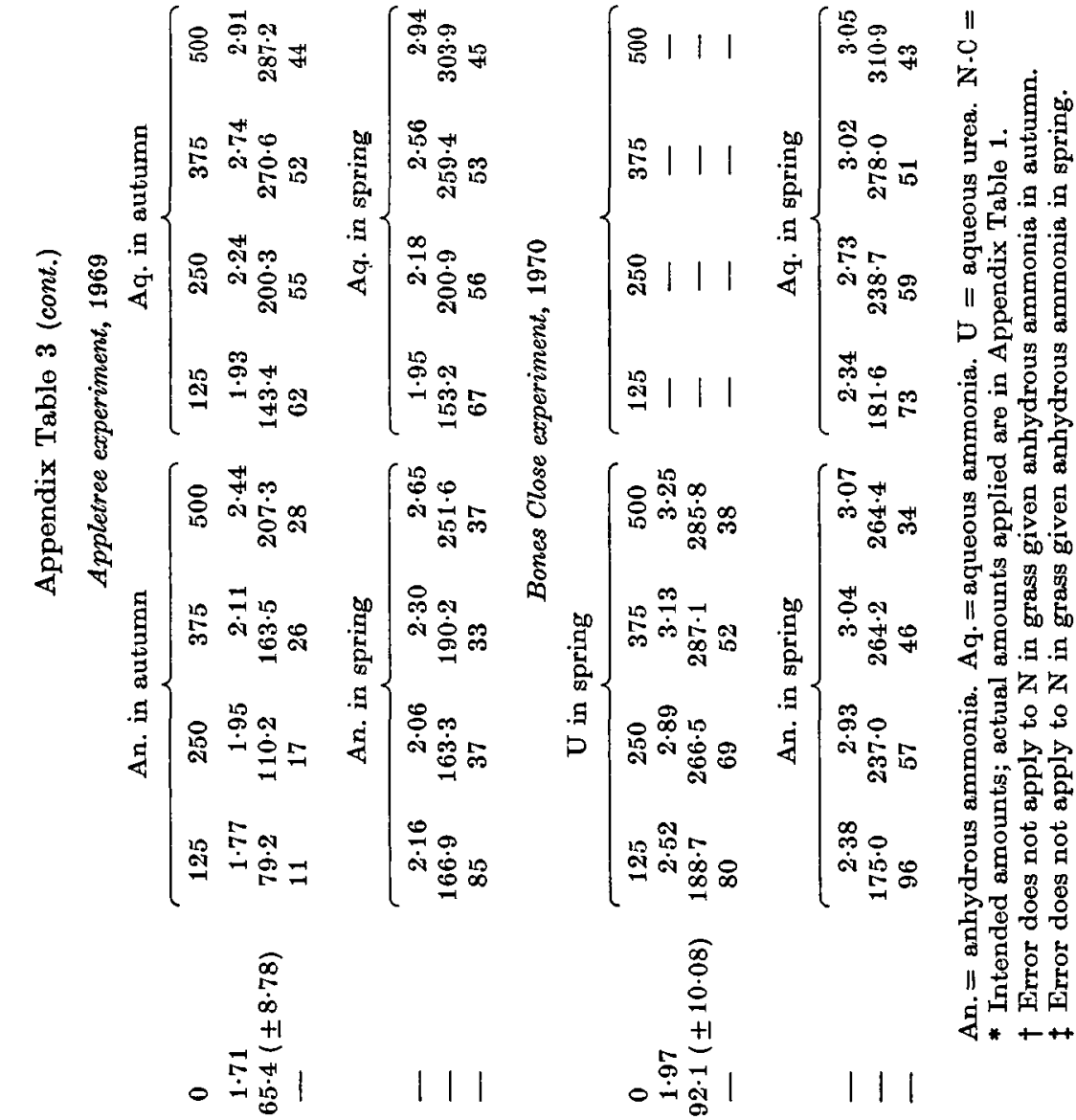

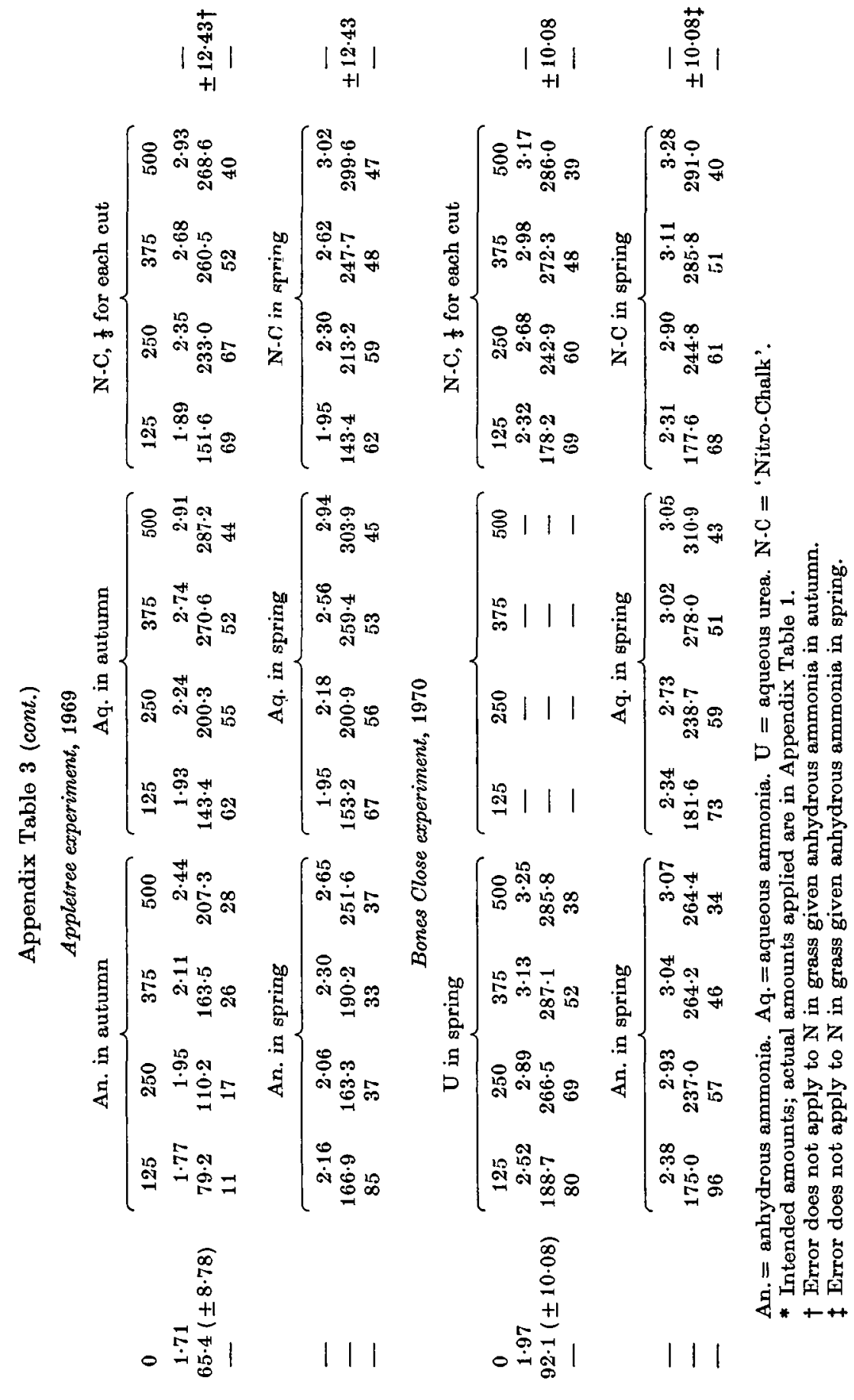

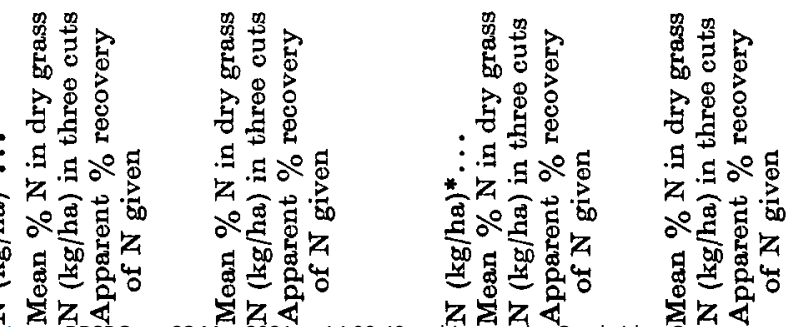

